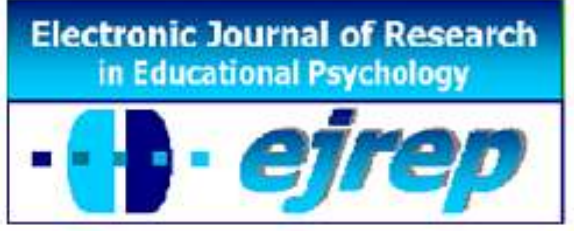

\title{
Exploring conceptions about writing and learning: undergraduates' patterns of beliefs and the quality of academic writing
}

\author{
Martínez-Fernández, J. R. ${ }^{1 *}$, Corcelles, M. ${ }^{2}$, Bañales, G. ${ }^{2}$, \\ Castelló, M. ${ }^{2}$, \& Gutiérrez-Braojos, C. ${ }^{3}$
}

Spain

Correspondence: J. Reinaldo Martínez-Fernámdez. Universitat Autònoma de Barcelona. Campus Bellaterra. Edifici G6. Despacho 215. Spain. E-mail: josereinaldo.martinez@uab.cat

(C) Education \& Psychology I+D+i and Ilustre Colegio Oficial de la Psicología de Andalucía Oriental (Spain) 


\section{Abstract}

Introduction. In this study, the conceptions of learning and writing of a group of undergraduates enrolled in a teacher education programme were identified. The relationship between them were analysed, and a set of patterns of beliefs about learning and writing were defined. Finally, the relation between these patterns and the quality of a text written during an examination situation were discussed.

Method. Fifty-two undergraduates from a large public Spanish university have taken part, most of them women (86\%), with a mean age of 21.39 years. They filled a questionnaire on writing conceptions and another on learning conceptions. Moreover, they compose an informative text about the development of identity during adolescence.

Results. The results support the existence of two dimensions as regards the conceptions of writing (cognitive and motivational) and three factors related to the conceptions of learning (rote, interpretative and deep).

Discussion and Conclusion. The relationship between them is not completely consistent. However, the deeper and positive motivational beliefs are related to better results in text quality, while the reproductive and negative motivational beliefs are related to worse results in text quality.

Keywords: writing conceptions; learning conceptions; undergraduates; academic writing. 


\section{Acercamiento a las concepciones sobre la escritura y el aprendizaje: patrones de creencias de los universitarios y la calidad de su redacción académica}

\section{Resumen}

Introducción. En este estudio, se identifican las concepciones de escritura y de aprendizaje de un grupo de estudiantes universitarios matriculados en los estudios de Ciencias de la Educación. Se analiza la relación entre ambas concepciones, y se define un conjunto de patrones de creencias acerca del aprendizaje y la escritura. Finalmente, se discute la relación entre los patrones de creencias identificados con la calidad de un texto escrito durante una situación de examen.

Método, Participan 52 estudiantes de una Universidad pública española, de ellos la mayoría son mujeres $(68 \%)$ con una edad media de 21.39 años. Los estudiantes respondieron un cuestionario sobre sus concepciones de escritura y otro sobre las concepciones de aprendizaje. Además, redactan un texto informativo acerca del desarrollo de la identidad durante la adolescencia.

Resultados. Los resultados apoyan la existencia de dos dimensiones con respecto a la concepción de escritura (cognitiva y motivacional) y de tres factores relacionados con la concepción de aprendizaje (directa, interpretativa y profunda).

Discusión o Conclusión: Las relaciones entre ellas no son del todo consistentes. Sin embargo, las creencias profundas y motivacionalmente positivas se relacionan con mejores resultados en la calidad del texto; mientras que las creencias reproductivas y motivacionalmente negativas se relacionan con peores resultados en cuanto a la calidad del texto.

Palabras Clave: concepción de escritura, concepción de aprendizaje, universitarios, escritura académica. 


\section{Introduction}

Undergraduate students often complete different academic writing assignments as part of their learning activities. Over the past decades, research on writing has shown that writing in disciplines is a complex activity for undergraduates because it involves a cognitive and motivational effort to do it while trying to fulfil the expectations of disciplinary communities (Bazerman, 2012; Bazerman et al., 2005; Berkenkotter \& Huckin, 1995; Castelló, Bañales, \& Vega, 2010; Castelló, Iñesta, Liesa, Pardo, \& Martínez-Fernández, 2012; Hidi \& Boscolo, 2007; Ryan, 2011). From this standpoint, writing and learning researchers in higher education have begun to investigate the effect that both types of conceptions have on the students' learning and success in academic outcomes. Despite the specific achievements gained in each of these research fields; no studies have been conducted that put these factors together in a more interrelated analysis about patterns of beliefs on learning and writing conceptions.

Regarding writing conceptions, different studies have shown their influence on the students' composition processes and text quality (Lavelle \& Guarino, 2003, Lavelle \& Zuercher, 2001; Sanders-Reio, Alexander, Reio, \& Newman, 2014; Villalón \& Mateos, 2009; White \& Bruning, 2005). As for learning conceptions, research results have clearly identified their influence on the students' approach to study and their direct or indirect (latent) influence on learning outcomes, particularly in the tertiary education context (Ellis, Goodyear, Calvo, \& Prosser, 2008; Marton, Dall'Alba, \& Beaty, 1993; Van Rossum \& Schenk, 1984; Yang \& Tsai, 2010). Despite these contributions from writing and learning studies, nowadays not much research intends to explain more in depth the relationships between the undergraduates' writing and learning conceptions and their relationship to a written academic text. Therefore, in this study we focus on three aspects: (1) identifying undergraduates' writing and learning conceptions; (2) analysing the relationship between these in order to define specific patterns of beliefs; and (3) analysing the relationship between these patterns through the quality of an academic text in an examination activity.

Additionally, in this exploratory study unusual assessment activity in the Spanish university context was proposed. This activity consisted in a written academic text in order to determine the cognitive and motivational writing beliefs involved therein, and to know their impact, or lack thereof, on academic performance. 


\section{Conceptions of writing}

Research on writing has tended to classify the factors involved in the composition process into two sets: cognitive (Alamargot \& Chanquoy, 2001) and motivational-affective factors (Bruning \& Horn, 2000; Hidi \& Boscolo, 2006; 2007). Regarding cognitive factors, research has highlighted the importance of strategic planning and review processes for the achievement of knowledge transformation and higher levels of text quality in academic writing tasks (Bereiter \& Scardamalia, 1987; 1992; Chanquoy, 2009; Rijlaarsdam \& van den Bergh, 2006). Regarding motivational-affective factors, research has indicated that most of them-such as attitudes towards writing productivity, procrastination, perception of selfefficacy as a writer, perfectionism, and writing blocks-have a decisive influence on the composition processes (Boice, 1993; Pajares \& Valiente, 2006).

Lavelle and Zurcher (2001) from a phenomenographic and cognitive approach, has focused on identifying student conceptions towards cognitive writing processes of planning, writing and revising. They noted that students could hold, at least, two major approaches to writing: deep and surface. Students with a deep approach conceive writing as an audienceoriented process and therefore they consider planning as flexible, taking into account global and local text levels in order to make their theses and ideas clear so as to reinforce them. In contrast, students who adopt a surface approach conceive writing as a process less oriented to the audience, taking into account planning at a local level, focusing on the revision of spelling aspects, based on a passive use of information, and showing low motivation towards the text production.

White and Bruning (2005) have identified two different types of beliefs: transactional and transmissive. Students who hold transmissive beliefs towards writing conceive it as a way to transfer information from authoritative sources to the reader, giving privilege to the ideas of text-source authors and minimising their own ideas with a low level of cognitive and affective involvement. In contrast, students who have transactional beliefs towards writing tend to adopt a higher cognitive and affective engagement during the writing process. Likewise, they conceive writing as a way to personally compose the text by taking into account, and integrating, other authors' ideas but with a critical view.

A more integrated approach has been taken by Lonka (1996; 2003; Lonka et al., 2014), who has developed an inventory to study the writing conceptions of university students 
considering cognitive and affective aspects of the writing processes. Regarding the cognitive aspects, her approach is based on the well-known Bereiter and Scardamalia $(1987 ; 1992)$ distinction between writing as a process of knowledge-telling and knowledge-transforming. Regarding the affective factors, her works consider variables such as procrastination, writing blocks and perfectionism based on Boice's work (1993; Boice \& Jones, 1984).

We have summarised the main theoretical assumptions which have been considered in this study regarding writing conceptions following the Lonka's work and the theoretical assumptions revised. In this respect, we identified two components -cognitive and motivational beliefs- with a positive or a negative way (see Table 1).

Table 1. Main theoretical assumptions about writing conceptions

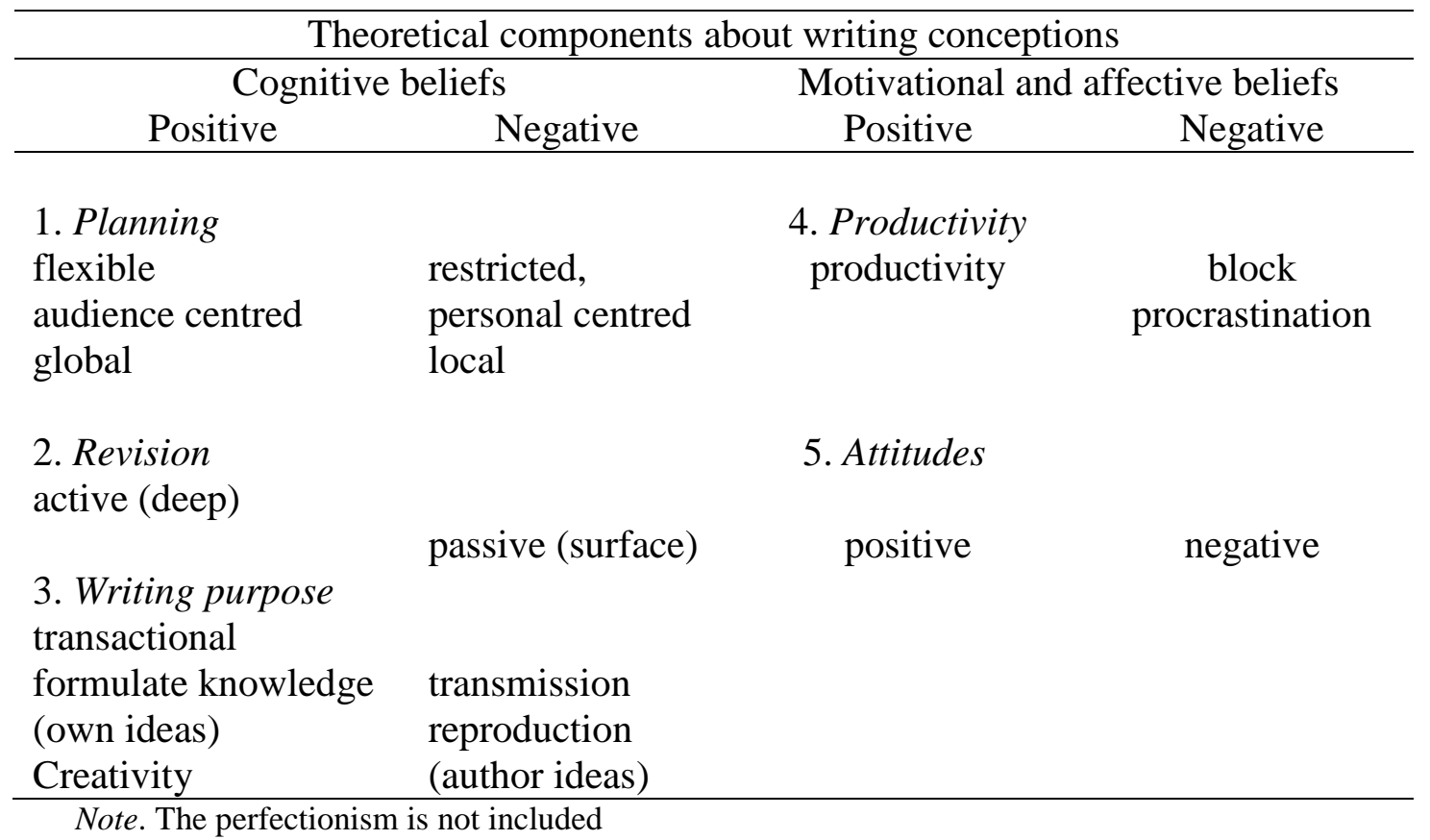

\section{Conceptions of learning}

Since the 1970s, many studies have inquired about how undergraduates conceive their learning as well as how these learning conceptions are related to their learning outcomes and other cognitive and motivational factors. From the phenomenographic tradition of Students' Approaches to Learning (SAL) two broad categories have been defined: surface and deep approaches (Biggs, 1994; Marton et al., 1993; Säljö, 1979). Recently, these conceptions of learning have been categorised as fragmented and cohesive (Ellis \& Calvo, 2006; Ellis et al., 2008; Yang \& Tsai, 2010), in a similar way to explain surface and deep conceptions, respec- 
tively. Students with fragmented conceptions understand learning as memorisation and reproduction of knowledge, and show disconnection between the learning environment and their learning success. In contrast, students with cohesive conceptions, conceive their learning as a conceptual and personal change because it allows them to restructure their previous knowledge and create new knowledge (Ellis et al., 2008). These two main categories are linked to the five conceptions identified by Säljö (1979): a) increasing one's knowledge, b) memorising, c) applying, d) understanding, e) seeing something in a different way; and f) changing as a person, a sixth conception identified by Marton et al. (1993). Whereas the first three conceptions are rather quantitative (surface approach), the other three are based on a qualitative or deep approach according to Biggs (1994). According to Haggis (2003) "both conceptions and approaches were seen to be linked to the way in which the student perceived the context of learning (p. 90)".

A different group of studies, from a cognitive perspective and close to the conceptual change framework (Posner, Strike, Hewson, \& Gertzog, 1982), stresses the analysis of previous knowledge and its consecutive change on account of the students' dissatisfaction with their current explanations. According to this framework, the students find better explanations to be plausible, useful and with potential to help them explain future phenomena. In this respect, this field has suggested that student learning conceptions are related to their epistemological beliefs on knowledge acquisition, which are classified in different theories of learning such as rote, interpretative and constructive (Martínez-Fernández, 2004; 2007; Pozo \& Scheuer, 1999, Pozo et al., 2006). Students who hold a rote conception of learning understand learning as a process to reproduce knowledge. In contrast, students with an interpretative conception suppose their cognitive activity is a crucial mediator between the learning conditions and their results, but learning is still considered a process of practicing and repeating until knowledge is acquired; probably a new variant of known conceptions of learning (Duarte, 2007). Finally, students with a constructive conception understand learning as a reconstructive process (knowledge transformation) (Pozo \& Scheuer, 1999).

After reviewing both research fields, we found theoretical congruent relationship between a deep, reflexive, transformative conception and the best learning outcomes; as also occurs between a rote, reproductive, transmissive conception and poor learning outcomes (like Haggis, 2003). However, this relationship is not sufficiently observed in tertiary education students (Lindblom-Ylänne \& Lonka, 2000; Lonka \& Lindblom-Ylänne, 1996). This 
indicates that the orchestration of the factors related to learning is not always harmonious, and not always do we find a clear and specific relation between deep learning conception and good learning outcomes (complex consonance like Cano, 2005). Accordingly, rote learning conception related to worse learning outcome (basic consonance) (Cano, 2005; MartínezFernández \& Vermunt, 2015; Meyer, 2000; Vermunt \& Verloop, 2000; Virtanen \& Lindblom-Ylänne, 2010). We think, that there is a relevant cultural explanation for the incongruence between rote learning conception with good learning outcomes; or deep learning conception with worse learning outcomes (Vermunt, Bronkhorst, \& Martínez-Fernández, 2014; Zhu, Valcke, \& Schellens, 2008).

In summary, while it is undeniable that research from both traditions has contributed to a better understanding of the writing and learning conceptions effects on learning outcomes. Nowadays, little is known about the relationships between learning and writing conceptions and their relationship with the quality of writing in case of undergraduates.

\section{The aims and hypotheses}

The aims of this study were: (1) to analyse the relationship between undergraduates' writing and learning conceptions in order to: (2) identify patterns of beliefs-conceptionsand (3) to analyse their relation to the quality of an academic text in an examination situation. According to the theoretical framework reviewed, the following hypotheses were proposed:

1. We expect to find a positive relationship between a deep conception of learning, positive cognitive involvement and a positive motivational affective involvement in writing. This pattern (complex consonance) would be positively related to the quality of the academic text.

2. In contrast, we expect to find a positive relationship between a rote conception of learning and a negative cognitive involvement with a negative motivational affective involvement in writing. This pattern (basic consonance) would be negatively related to the quality of the academic text. 


\section{Method}

\section{Participants}

The sample comprised 52 undergraduates enrolled in the Developmental Psychology class of a large public Spanish university. Their mean age was 21.39 ( $S D=3.18)$ and there were $86 \%$ of women. This group represents $50 \%$ of the total students in their third year of tertiary education in a Teacher Education Programme that can be completed in four years. Participation was voluntary. Normally, the evaluation activities in this system are multiple choice tests, or team report activities without personal reflections.

\section{Instruments}

The Writing Process Questionnaire (Lonka, 1996). Lonka's writing inventory (1996) were translated and adapted in order to identify students' writing conceptions. The original version comprised 25-item scale distributed in nine factors (see Table 2); and more recently Lonka, Chow, Keskinen, Hakkarainen, Sandström, and Pyhältö (2014) proposed a structure based on six factors (block, procastination, perfectionism, innate ability, knowledge transforming, and productivity). However, in this exploratory study, and based on the theroretical framework, expert judgement, and after some exploratory analyses to test alpha Cronbach reliability and content validity for this inventory, a structure of four sub-scales according to cognitive and motivational writing components in two ways (positive and negative involvement) was suggested. The Cronbach's alpha index show that the sub-scales referring to motivational involvement in writing yield well indexes (.86 and .71); whereas the other two, referring to cognitive involvement, yield lower indexes (. 55 and .56).

Given that this inventory is still an exploratory measure to assess writing conceptions, here were assumed indexes around .60 as acceptable (Hair, Anderson, Tatham, \& Black, 1998; Robinson, Shaver, \& Wrightsman, 1991). The sub-scale referring to perfectionism yields an inadequate reliability index; for this reason, it to not was consider in the following analysis. Factor analysis do not was possible to apply in this sample, because psychometrics indicators (KMO and Bartlett's test) are inadequate, and the sample size was small. However, recently research declare that this questionnaire is a reliable and valid tool, and it captures some essentiall aspects of academic writing process and its emotional dimensions. 
The results from Pearson's correlations between the cognitive and motivational subscales, defined in this study, show that positive and negative motivational involvement yield significant negative relationships $(r=-.58 ; p<.01)$ between themselves in a logical way. However, a significant positive relationship between positive motivational involvement with negative cognitive involvement in writing $(r=.39 ; p<.01)$ was observed.

\section{Table 2. Theoretical structure and reliability according Lonka's sub-scales about writing conceptions}

\begin{tabular}{|c|c|c|}
\hline $\begin{array}{l}\text { Factors in this study and nine sub-scales ac- } \\
\text { cording to Lonka proposal }\end{array}$ & Items example: & $\alpha$ \\
\hline \multicolumn{3}{|l|}{ - Positive cognitive involvement } \\
\hline Formulating knowledge/information (1) & I usually revise my writing several times & .55 \\
\hline Writing as a creative activity (9) & Writing is a creative activity & \\
\hline \multicolumn{3}{|l|}{ - Negative cognitive involvement } \\
\hline Reproducing Knowledge/information (2) & I think writing is a private matter... & .56 \\
\hline \multicolumn{3}{|l|}{ - Positive motivational-affective involvement } \\
\hline Positive attitudes (3) & I think writing is easy & .86 \\
\hline Productivity (4) & I write whenever I have the chance & \\
\hline \multicolumn{3}{|l|}{ - Negative motivational-affective involvement } \\
\hline Procrastination (5) & I postpone the task of writing... & .71 \\
\hline Writer's block (6) & Without deadlines I would not produce... & \\
\hline Negative thoughts (8) & I hate writing & \\
\hline - Perfectionism (7) & I could revise my written work endlessly & .06 \\
\hline
\end{tabular}

(1) Audience centred, deep and flexible / (2) Personal centred, surface and restricted

Conceptions of Learning Questionnaire (Martínez-Fernández, 2004; 2007). To determine the students' conceptions of learning were used the CONAPRE questionnaire (MartínezFernández, 2004; 2007; Rabanaque \& Martínez-Fernández, 2009). This instrument comprises fourteen items distributed into three sub-scales: two of them regard the two traditional learning conceptions: rote (e.g., I read information twice, three or four times in order to be able to repeat it), and deep conceptions (e.g., On the basis of new information, I make changes, transform and/or grow personally in the perception of myself as a person); the third one, labelled as interpretative, is related to knowledge application (e.g., I know how to reproduce information and understand its meaning). 
The exploratory factor analysis (EFA) using varimax rotation showed adequate psychometric properties $\left(\mathrm{KMO}=.50\right.$; Bartlett-test $\left.\chi^{2}=215.88 ; p<.01\right)$ in relation to its theoretical and empirical structure (Martínez-Fernández, 2004, 2007; Rabanaque \& MartínezFernández, 2009) (see Table 3).

Table 3. Factor analysis for the Conceptions of Learning Questionnaire - CONAPRE. Factor loadings according to principal component with varimax rotation $(N=52)$ (loading < .30 and $>-.30$ are omitted).

\begin{tabular}{|c|c|c|c|}
\hline Items & F1 & $\mathrm{F} 2$ & F3 \\
\hline 1. Have access to information and know exactly when to use it... & & & .75 \\
\hline 2. Analyze academic situations and application... & & & .67 \\
\hline 3. Memorizing information... & .82 & & \\
\hline 4. Consider different perspectives... & & .62 & \\
\hline 5. Produce new situations based on new ones... & & .40 & .32 \\
\hline 6. Read and re-read to be able to repeat the information... & .55 & & \\
\hline 7. Understand academic content and application... & & & .87 \\
\hline 8. Make changes, transform, and/or grow... & & .56 & \\
\hline 9. Reproduce information and comprehension understanding... & & .54 & \\
\hline 10. Recall information in order to repeat it.. & .76 & & \\
\hline 11. Plan challenges based on new information... & & .73 & \\
\hline 12. Apply prior information... & & .61 & \\
\hline 13. Relate different information... & & .46 & .42 \\
\hline 14. Attempt to memorize all of the information... & .85 & & \\
\hline $\begin{array}{l}\text { Total variance explained }=50.92 \% \\
\text { F1: rote conception of learning }(21.22 \%) \\
\text { F2: deep conception of learning }(17.15 \%) \\
\text { F3: interpretative -apply conception of learning }(12.55 \%) \\
(\mathrm{KMO}=.50)\left(\chi^{2} \text { Bartlett }=215.88 ; p<.01\right)\end{array}$ & & & \\
\hline
\end{tabular}

Three factors which are representative of three different conceptions were identified: rote conception (Cronbach's $\alpha=.75$ ), deep conception (Cronbach's $\alpha=.67$ ) related to some interpretative items, and a third factor linked to an interpretative-apply conception (Cronbach's $\alpha=.72$ ) with items that emphasize the application of knowledge. The three subscales showed acceptable alpha reliability indexes. Pearson correlation analyses show that there were no significant relationships between any of the three factors.

The academic writing task

The writing assignment was an assessment task requiring the students to compose an informative text about the development of identity during adolescence. This topic belonged to one of the thematic units of the Developmental Psychology course. The students had to use a set of 10 concepts or authors of their choice in their writing out of 20 proposed choices (e.g., 
self-esteem, self-concept, attachment, identity, Piaget, Vigotsky, Erikson, etc.). The text could be addressed to parents, adolescents or teachers. In this sense, the students had to consider their audience and their goal with their text.

\section{Procedure}

First, the students performed their individual writing assignment and then they responded to the writing and learning conceptions questionnaires. It was a class-wide activity lasting approximately two hours in an examination situation. Next, each text-task was read and scored by two independent academic writing experts. These experts are researchers who have conducted a doctorate programme on psychology and academic writing. The texts were evaluated in terms of two dimensions: quality of content and quality of text organization; and they were scored from 1 to 5 points based on a Likert scale.

In the quality of content dimension was assessed the correctness of the definition given in the text, the use of appropriate examples to illustrate them and to involve the reader, and the correctness of the relationships between the concepts; for example: the implications of attachment on adolescence identity or Piaget's theory on moral development. In the organization dimension whether the text had an introduction to the topic to guide the reader, the logic development of ideas by using appropriate connectors and the quality of the conclusion were evaluated. The score for each paper was the mean of the two experts. The agreement index between the evaluators was $.89(p<.01)$ by the Kappa index. Additionally, the texts were also evaluated by the course teacher, who took into account course criteria (content, examples and personal reflections) according to the course's aims, scoring from 0 to 10 points to obtain academic performance.

\section{Data Analysis}

The data were analysed by means of descriptive, exploratory factor analyses, Pearson's correlations, multiple regression, and cluster analyses following the k-means procedure and one-way ANOVA and the effect size (Cohen, 1988) to analyse the differences in the means. 


\section{Results}

\section{Relationships between writing and learning conceptions}

To attain our first aim, Pearson correlation analyses between the different factors identified for the writing and learning conceptions were conducted. The results showed that the rote conception of learning has a significant positive relationship with a negative motivational involvement in writing $(r=.38 ; p<.01)$, in accordance with our second hypothesis. Additionally, the interpretative-apply conception has a significant positive relationship with a positive motivational involvement in writing $(r=.33 ; p=.02)$. The deep learning conception has a significant positive relationship with a positive motivational involvement in writing $(r=.29$; $p=.05)$, and a significant negative relationship with a negative motivational involvement in writing $(r=-.38 ; p<.01)$, in agreement with our first hypothesis. In sum, relevant links between motivational beliefs about writing and learning conceptions were found, but no significant relationships between cognitive beliefs about writing (neither positive nor negative) and learning conceptions.

\section{Quality of the academic text}

Regarding text quality, several significant positive relationships were found between different text measures (content, organisation and academic score). A strong correlation was found between content quality assessed by experts and the mark assigned by the course teacher $(r=.73 ; p<.01)$. Likewise, a significant relationship between text organisation and academic score $(r=.31 ; p=.02)$, and between text organisation and content $(r=.49 ; p<.01)$ were found. The academic score shows a negative correlation with a negative cognitive involvement ( $r=-.40 ; p=.01)$. Likewise, a negative correlation between the quality of the content and a negative cognitive involvement $(r=-.31 ; p=.03)$ was observed, in accordance with our second hypothesis. Moreover, a negative correlation between the quality of text organisation with a deep conception of learning $(r=-.48 ; p<.01)$ was found, in disagreement with our first hypothesis.

Exploring patterns of conceptions about writing and learning and their relation to quality of academic writing

Taking into account the aforementioned results, and in accordance with our second and third aim, different correlation, regression and cluster analyses in order to identify spe- 
cific patterns of beliefs about writing and learning, and their relation to the quality of academic writing were conducted. The regression analysis taking into account different variable combinations revealed unsatisfactory results. Cluster analyses using all the factors with a kmeans procedure were also conducted, as well as using only motivational factors or cognitive together with learning conceptions combined with the text quality variables. We considered the different results by Cluster analyses in order to discriminate between different groups by using theoretical assumptions and other empirical indicators (e.g., ANOVA, distribution in each cluster, discriminate analysis). Through this procedure two specific patterns were found where $91.7 \%$ of the originally cases grouped were classified correctly according to the discrimination index (see Table 4).

Table 4. Patterns of beliefs about writing and learning conceptions and text quality

\begin{tabular}{|c|c|c|c|c|c|}
\hline \multirow[t]{2}{*}{$\begin{array}{c}\text { VARIABLES } \\
M(S D) \\
\end{array}$} & \multicolumn{2}{|c|}{ Clusters } & \multicolumn{3}{|c|}{ Statistical values } \\
\hline & $\begin{array}{c}1 \\
N=34\end{array}$ & $\begin{array}{c}2 \\
N=18\end{array}$ & $F(1,52)$ & $p$ & $d$ \\
\hline \multicolumn{6}{|l|}{ Conceptions of learning } \\
\hline \multicolumn{6}{|l|}{ Rote conception } \\
\hline $11.50(3.22)$ & $10.89(2.80)$ & $12.89(3.76)$ & 3.72 & .04 & .60 \\
\hline \multicolumn{6}{|l|}{ Interpretative conception } \\
\hline $10.06(1.81)$ & $10.28(1.68)$ & $9.56(2.03)$ & 2.29 & .19 & .39 \\
\hline \multicolumn{6}{|l|}{ Deep conception } \\
\hline $24.69(3.43)$ & $25.72(3.33)$ & $22.38(2.45)$ & 14.40 & $<.01$ & 1.14 \\
\hline \multicolumn{6}{|l|}{ Conceptions of writing } \\
\hline $\begin{array}{l}\text { Positive motivation } \\
25.83(5.44)\end{array}$ & $28.09(4.42)$ & $21.31(4.45)$ & 25.01 & $<.01$ & 1.53 \\
\hline \multicolumn{6}{|l|}{ Negative motivation } \\
\hline $38.92(6.95)$ & $35.19(4.28)$ & $46.38(4.92)$ & 65.85 & $<.01$ & 2.43 \\
\hline \multicolumn{6}{|l|}{ Text quality } \\
\hline $\begin{array}{l}\text { Text academic performance } \\
7.54(1.67)\end{array}$ & $7.88(1.46)$ & $6.77(1.90)$ & 4.70 & .03 & .63 \\
\hline \multicolumn{6}{|l|}{ Organization text } \\
\hline $2.86(.66)$ & $2.76(.63)$ & $3.09(.70)$ & 3.39 & .09 & .50 \\
\hline \multicolumn{6}{|l|}{ Quality of content } \\
\hline $3.30(.84)$ & $3.34(.85)$ & $3.21(.83)$ & 1.34 & .60 & .15 \\
\hline
\end{tabular}


The first group $(N=34 ; 65 \%)$ comprised students with positive motivational involvement about writing (productivity and positive attitudes) who had deeper learning beliefs than the other group, and they had better academic performance and better content quality. Moreover, they had lower scores in the rote conception of learning and a negative motivational involvement. This group was labelled deeper and positive motivational-oriented beliefs regarding learning and writing.

The second group $(N=18 ; 35 \%)$ included students with a negative motivational involvement (writers' block, procrastination and negative attitudes) who tended to have a rote learning conception. They presented lower scores on the deep conception, on positive motivational involvement and on performance and quality of text content. This group was labelled reproductive and negative motivational-oriented beliefs regarding learning and writing.

It is noteworthy that, contrarily to what was expected, the subjects in the second group obtained a higher score on text organisation with a medium effect size $(d=.50)$ as compared to those in the first group. In general, a strong effect size (Cohen, 1988, p. 36) in negative motivation $(d=2.43)$, positive motivation $(d=1.53)$ and deep conception $(d=1.14)$ between two groups were observed. Likewise, there is a medium effect size on text academic performance $(d=.63)$ and rote conception $(d=.60)$.

\section{Discussion and Conclusions}

The main goal of this study was to analyse the relationships between learning conceptions and writing conceptions, in order to identify patterns of believe about writing and learning conceptions on undergraduates. Moreover, the association between these patterns with some variables regarding the quality of an academic text composed in an examination situation were discussed.

\section{Writing conceptions}

Regarding the writing conceptions, two clear factors related to cognitive involvement (positive and negative) and two related to motivational-affective involvement (positive and negative) were found. The two cognitive factors show a lower reliability index: one of them concerning the formulation of knowledge (positive), and the other concerns to reproduction of knowledge (negative) (Lavelle \& Zurcher, 2001; Villalón \& Mateos, 2009). The two factors 
concerning motivational involvement are: one of them oriented to productivity and positive attitudes, and the other concerning procrastination, blocking and negative thought (according to Lonka, 1996; 2003; Lonka et al. 2014). Regarding the relationships between these factors, a dissonant relationship between a positive motivational involvement (positive attitudes and productivity) and a negative cognitive involvement (reproduction of knowledge and a low level of planning and revision during the writing process) were found; contrary to White and Bruning (2005), and Sanders-Reio et al. (2014). Probably, this relationship (positive motivational involvement with a negative cognitive involvement) in this Spanish sample could be a consequence of the Spanish traditional evaluation of learning in secondary and tertiary education based on multiple choice tests, which tends to involve reproductive tasks most of the time. This would account for students linking their positive motivational involvement to reproduction because it had proved useful in the past to obtain good marks.

\section{Learning conceptions}

Two classical rote and deep conceptions were identified (Biggs, 1994; Marton et al., 1993; Säljö, 1979), and a third one related to an interpretation-application view of knowledge (Duarte, 2007; Pozo \& Scheuer, 1999; Pozo et al., 2006; Martínez-Fernández, 2004; 2007) was found, too. These three different factors are independent from each other. In this respect, we cannot defend a vision of category opposites, but the conceptions do not seem to be related, either. Probably, we need to analyse more in depth the conceptions of learning because it is possible that we can find some cultural reasons to explain these results (Duarte, 2007; Vermunt, Bronkhorst, \& Martínez-Fernández, 2014; Zhu, Valcke, \& Schellens, 2008). The relationship between writing and learning conceptions is congruent in general. On the one hand, the rote conception of learning is related to a negative motivational involvement in writing. On the other, a deep conception of learning is negatively related to a negative motivation, and positively related to a positive motivational involvement in writing. Moreover, an interpretative conception of learning is related to a positive motivational involvement.

\section{Patterns of beliefs and academic writing}

In this study two patterns of beliefs were identified. The first pattern, identified as deeper and positive motivational beliefs in writing, confirms some of the previous research showing the relevant role of formulating knowledge, which is characteristic of a deep or cohesive conception of learning (Ellis \& Calvo, 2006; Yang \& Tsai, 2010), and their complex consonant relationships in explaining good performance (Lindblom-Ylänne \& Lonka, 2000; 
Lonka et al., 2014; White \& Bruning, 2005). This result supports our first hypothesis (complex consonance): although it does not include the cognitive involvement factor contrary to Alamargot and Chanquoy (2001) and Lavelle and Zucher (2001) findings. The complex congruence is only explained from the deep conception of learning and a positive motivational involvement in writing. As for the second pattern, named reproductive and negative motivational beliefs in writing, it is linked to procrastination, blocking and negative thoughts, to a reproductive conception of learning and a lower performance (Boice, 1993; Lonka et al., 2014; Pajares \& Valiente, 2006; Rose, 1984). This result supports our second hypothesis of a basic consonance between the rote conception of learning and a negative motivational involvement in writing, which is also related to the so-called fragmented conception (Ellis et al., 2008).

Regarding the academic writing task, it seems the students with a more organised text are closer to a reproductive pattern and this was related to a lower quality in the text's content and in academic performance. The students with a deeper and positive motivational involvement in writing are related to higher quality texts as regards their content and academic performance, although the latter are not the best organised texts.

Finally, and notwithstanding that this study is more exploratory about the writing inventory proposed by Lonka (1996) on a small sample size; but it is a good measure in order to identify academic writing conceptions and with interesting application cross-cultural. However, it is necessary to conduct more research on this questionnaire using larger samples. In this study, it was used in an exploratory way in order to discuss their relationship with the quality of a text written.

\section{Conclusions}

It seems clear that there exist two patterns of beliefs about writing and learning related to the quality of an academic text, and these patterns are more based to the motivational involvement in writing and the conceptions of learning than to the cognitive involvement in writing. In this respect, we support the findings of Boice (1993), and Pajares and Valiente (2006), when they underline that motivational aspect have a decisive influence on the composition processes. So, from an educational point of view, it seems that we should foster positive attitudes and orientation towards productivity along with deep conceptions of learning in order to activate knowledge-transformation processes (Ryan \& Ryan, 2013). 
Taking into account our theoretical and empirical grounds, it can set forth some suggestions to support students to learn in a constructive and transformative way according to Ryan and Ryan (2013). Below are some examples of these main issues: (1) suggesting a list of matters to write some essays; (2) proposing certain problems to try gather ideas to figure out educational troubles which will help write a research or intervention project; (3) stimulating personal interest about learning and instruction, fostering teacher education students to write a personal diary about their interests, feelings and thoughts; (4) motivating critical peer revisions in order to improve the incorporation of the author's voice in their texts; and (5) choosing relevant books, papers and other materials to build a strong theoretical and conceptual - lexical - foundation. All this assuming a positive and productive attitude towards writing.

In sum, we think that educators need to stimulate their students (in an explicit and strategic intervention) with activities, issues and materials in line with the above-mentioned issues. Moreover, if they use different types of assessing activities based on writing skills, we will encourage a constructive way of learning in a more integrated and complex congruent view that put together motivational and cognitive students beliefs about writing and learning.

\section{References}

Alamargot, D., \& Chanquoy, L. (2001). Through the models of writing. Dordrecht: Kluwer Academic Publishers.

Bazerman, C. (2012). Writing with concepts: communal, internalized, and externalized. Mind, Culture, and Activity, 19(3), 259-272.

Bazerman, C., Little, J., Chavkin, T., Fouquette, D., Bethel, L., \& Garufis, J. (2005). Writing across the curriculum. Reference guides to rhetoric and composition, Parlor Press and WAC Clearinghouse. Retrieved from: http://wac.colostate.edu/books/bazerman_wac/

Bereiter, C., \& Scardamalia, M. (1987). The psychology of written composition. Hillsdale, NJ: Lawrence Erlbaum Associates.

Bereiter, C., \& Scardamalia, M. (1992). Dos modelos explicativos de los procesos de composición escrita [Two explicative models for the processes of written composition]. Infancia y Aprendizaje, 15(2), 43-64. 
Berkenkotter, C., \& Huckin, T. N. (1995). Genre Knowledge in Disciplinary Communication. Mahwah, NJ: LEA.

Biggs, J. B. (1994). Student learning research and theory: Where do we currently stand? In G. Gibbs (Ed.), Improving Student Learning: Using Research to Improve Student Learning, (pp. 1-19). Oxford: Oxford Centre for Staff Development.

Boice, R., \& Jones F. (1984). Why academicians don't write. The Journal of Higher Education, 55(5), 567-582. doi:10.2307/1981822

Boice, R. (1993). Writing blocks and tacit knowledge. The Journal of Higher Education, 64(1), 19-54. doi:10.2307/2959976

Bruning, R., \& Horn, C. (2000). Developing motivation to write. Educational Psychologist, 33(1), 25-37. doi:10.1207/S15326985EP3501_4

Cano, F. (2005). Consonance and dissonance in students' learning experience. Learning and Instruction, 15, 201-223. doi:10.1016/j.learninstruc.2005.04.003

Cano, F. (2007). Approaches to learning and study orchestrations in high school students. European Journal of Psychology of Education, 22(2), 131-151. doi:10.1007/BF03173518

Castelló, M., Bañales, G., \& Vega, N. (2010). Research approaches to regulation of academic writing: State of the art. Electronic Journal of Research in Educational Psychology, 8, 1253-1282.

Castelló, M., Iñesta, A., Pardo, M., Liesa, E., \& Martínez-Fernández, J. R. (2012). Tutoring the end-of-studies dissertation: helping psychology students find their academic voice when revising academic text. Higher Education, 63(1), 97-115. doi:10.1007/s10734$\underline{011-9428-9}$

Chanquoy, L. (2009). Revision Processes. In R. Beard, D. Myhill, J. Riley, \& M. Nystrand (Eds.), The SAGE Handbook of Writing Development, (pp. 80-97). London: SAGE Publications.

Cohen, J. (1988). Statistical Power Analysis for the Behavioral Sciences. Second edition. Hillsdate, NJ: LEA.

Duarte, A. M. (2007). Conceptions of learning and approaches to learning in Portuguese students. Higher Education, 54, 781-794. doi:10.1007/s10734-006-9023-7

Ellis, R. A., \& Calvo, R. (2006). Discontinuities in university student experiences of learning through discussions. British Journal of Educational Technology, 37, 55-68. doi:10.1111/j.1467-8535.2005.00519.x 
Ellis, R. A., Goodyear, P., Calvo, R. A., \& Prosser, M. (2008). Engineering students' conceptions of and approaches to learning through discussions in face-to-face and online contexts. Learning and Instruction, 18, 267-282. doi:10.1016/j.learninstruc.2007.06.001

Haggis, T. (2003). Constructing images of ourselves? A critical investigation into 'approaches to learning' research in Higher Education. British Educational Research Journal, 29(1), 89-104. doi: 10.1080/0141192032000057401

Hair, J. F., Anderson, R. E., Tatham, R. L., \& Black, W. C. (1998). Multivariate data analysis. Upper Saddle River, NJ: Prentice Hall International.

Hidi, S., \& Boscolo, P. (2006). Motivation and writing. In C. A. MacArthur, S. Graham, \& F. Fitzgerald (Eds.), Handbook of writing research, (pp. 144-157). New York: The Guilford Press.

Hidi, S., \& Boscolo, P. (2007). The multiples meanings of motivation to write. In S. Hidi, \& P. Boscolo (Eds.), Writing and Motivation, (pp. 1-15). Amsterdam: Elsevier.

Lavelle, E., \& Guarino, A. J. (2003). A multidimensional approach to understanding college writing Processes. Educational Psychology, 23, 295-305. doi: $10.1080 / 0144341032000060138$

Lavelle, E., \& Zuercher, N. (2001). The writing approaches of university students. Higher Education, 42, 373-391. doi:10.1023/A:1017967314724

Lindblom-Yläine, S., \& Lonka, K. (2000). Dissonant study orchestration of high-achieving university students. European Journal of Psychology of Education, 15, 19-32.

Lonka, K. (1996). The writing process questionnaire. Department of Psychology, University of Helsinki.

Lonka, K. (2003). Helping doctoral students to finish their thesis. In: L. Bjork, G. Brauer, L. Rienecker, \& P. S. Jorgensen (Ed.), Teaching Academic Writing in European Higher Education, (pp. 113-131). Netherlands: Kluwer Academic Publishers.

Lonka, K., \& Lindblom-Yläine, S. (1996). Epistemologies, conceptions of learning, and study practices in medicine and psychology. Higher Education, 31, 5-24. doi:10.1007/BF00129105

Lonka, K., Chow, A. Keskinen, J., Hakkarainen, K. Sandström, N., \& Pyhältö, K. (2014). How to measure $\mathrm{PhD}$ students' conceptions of academic writing? Journal of Writing Research, 5(3), 245-269.

Martínez-Fernández, J. R. (2004). Concepción de aprendizaje, metacognición y cambio conceptual en estudiantes universitarios de psicología [Conceptions of learning, metacognition and conceptual change of psychology undergraduates]. Doctoral Dissertation. 
University of Barcelona, Barcelona, Spain. Available on: http://www.tdr.cesca.es/TDX-1006104-091520/

Martínez-Fernández, J. R. (2007). Concepción de aprendizaje y estrategias metacognitivas en estudiantes universitarios de psicología [Conception of learning and metacognitive strategies in psychology undergraduates]. Anales de Psicología, 23(1), 7-16.

Martínez-Fernández, J. R., \& Vermunt, J. D. (2015). A cross-cultural analysis on the patterns of learning and academic performance of Spanish and Latin-American undergraduates. Studies in Higher Education, 40(2), 278-295. doi:10.1080/03075079.2013.823934.

Marton, F., Dall'Alba, G., \& Beaty, E. (1993). Conceptions of learning. International Journal of Educational Research, 19, 277-299.

Meyer, J. H. F. (2000). The modeling of "dissonant" study orchestration in higher education. European Journal of Psychology of Education, 15, 5-18. doi:10.1007/BF03173163

Pajares, F., \& Valiente, G. (2006). Self-efficacy beliefs and motivation in writing development. In C. A. Macarthur, S. Graham, \& F. Fitzgerald (Eds.), Handbook of writing research, (pp. 158-170). New York, NY: The Guilford Press.

Posner, G. J., Strike, K. A., Hewson, P. W., \& Gertzog, W. A. (1982). Accomodation of a scientific conception: Toward a theory of conceptual change. Science Education, 66, 211-227. doi:10.1002/sce.3730660207

Pozo, J. I., Scheuer, N., Pérez Echeverría, M. P., Mateos, M., Martín, E., \& De La Cruz, M. (Eds.). (2006). Nuevas formas de pensar la enseñanza y el aprendizaje: Las concepciones de profesores y alumnos [New ways for thinking about teaching and learning: the conceptions of teachers and students]. Barcelona: Graó.

Pozo, J. I., \& Scheuer, N. (1999) Las concepciones sobre el aprendizaje como teorias implícitas [Conceptions about learning as implicit theories]. In J. I. Pozo \& C. Monereo, El aprendizaje estratégico, (pp. 87-108). Madrid. Santillana.

Rabanaque, S., \& Martínez-Fernández, J. R. (2009). Conception of learning and motivation of Spanish psychology undergraduates in different academic levels. European Journal of Psychology of Education, 24(4), 513-528. doi:10.1007/BF03178765

Rijlaarsdam, G., \& van den Bergh, H. (2006). Writing Process Theory. A functional dynamic approach. In C. A. MacArthur, S. Graham \& F. Fitzgerald (Eds.), Handbook of Writing Research, (pp. 41-53). New York: The Guilford Press.

Robinson, J. P., Shaver, P. R., \& Wrightsman, L. S. (1991). Criteria for scale selection and evaluation. In J. P. Robinson, P. R. Shaver \& L. S. Wrightsman (Eds.). Measures of personality and social psychological attitudes. San Diego, Calif: Academic press. 
Rose, M. (1984). Writer's Block: The Cognitive Dimension. Carbondale: Southern Illinois UP.

Ryan, M. (2011). Improving reflective writing in higher education: a social semiotic perspective. Teaching in Higher Education, 16(1), 99-111. doi:10.1080/13562517.2010.507311

Ryan, M., \& Ryan, M. (2013). Theorising a model for teaching and assessing reflective learning in higher education. Higher Education Research \& Development, 32(2), 244-257. doi:10.1080/07294360.2012.661704

Säljö, R. (1979). Learning in the learner's perspective: I. Some common-sense conceptions. Reports from the Institute of Education, University of Gothenburg, 76.

Sanders-Reio, J., Alexander, P., Reio, T. G., \& Newman, I. (2014). Do students' beliefs about writing relate to their writing self-efficacy. apprehension, and performance? Learning and Instruction, 33, 1-11. doi:org/10.1016/j.learninstruc.2014.02.001

Van Rossum, E. J. \& Schenk, S. (1984). The relationship between learning conception, study strategies and learning outcome. British Journal of Educational Psychology, 54(1), 73 83.

Vermunt, J. D., Bronkhorst, L., \& Martínez-Fernández, J. R. (2014). The dimensionality in student learning patterns in different cultures. In: D. Gijbels, V. Donche, J. Richardson, \& J. D. Vermunt (eds). Learning Patterns in Higher Education: Dimensions and Research Perspectives (pp. 33-55). New Perspectives on Learning and Instruction, serie. New York: Routledge.

Vermunt, J. D., \& Verloop, N. (2000). Dissonance in students' regulation of learning processes. European Journal of Psychology of Education, 15(1), 75-87. doi:10.1007/BF03173168

Vermunt, J. D., \& Vermetten, Y. J. (2004). Patterns in student learning: relationships between learning strategies, conceptions of learning, and learning orientations. Educational Psychology Review, 16, 359-384. doi:10.1007/s10648-004-0005-y

Villalón, R., \& Mateos, M. (2009). Concepciones sobre la escritura académica de estudiantes de secundaria y universidad [Secondary and university students' conceptions about academic writing]. Infancia y Aprendizaje, 32(2), 219-232. doi:10.1174/021037009788001761

Virtanen, V., \& Lindblom-Ylänne, S. (2010). University students' and teachers' conceptions of teaching and learning in the biosciences. Instructional Science, 38, 355-370. doi:10.1007/s11251-008-9088-Z 
White, M. J., \& Bruning, R. (2005). Implicit writing beliefs and their relation to writing quality. Contemporary Educational Psychology, 30(2), 166-189. doi:10.1016/j.cedpsych.2004.07.002

Yang, Y. F., \& Tsai, C. C. (2010). Conceptions of and approaches to learning through online peer assessment. Learning and Instruction, 20, 72-83. doi:10.1016/j.learninstruc.2009.01.003

Zhu, C., Valcke, M., \& Schellens, T. (2008). The relationship between epistemological beliefs, learning conceptions, and approaches to study: a cross-cultural structural model? Asian Pacific Journal of Education, 28(4), 411-423. doi:10.1080/02188790802468823 
Martínez-Fernández, et al.

[This page intentionally left blank] 